\title{
Genetic parameters and breeding strategies for high levels of iron and zinc in Phaseolus vulgaris $\mathrm{L}$.
}

S.M. Martins ${ }^{1}$, P.G.S. Melo ${ }^{1}$, L.C. Faria ${ }^{2}$, T.L.P.O. Souza ${ }^{2}$, L.C. Melo ${ }^{2}$ and H.S. Pereira ${ }^{2}$

${ }^{1}$ Escola de Agronomia, Universidade Federal de Goiás, Goiânia, GO, Brasil

${ }^{2}$ Embrapa Arroz e Feijão, Santo Antônio de Goiás, GO, Brasil

Corresponding author: H.S. Pereira

E-mail: helton.pereira@embrapa.br

Genet. Mol. Res. 15 (2): gmr.15028011

Received November 6, 2015

Accepted April 15, 2016

Published June 10, 2016

DOI http://dx.doi.org/10.4238/gmr.15028011

\begin{abstract}
One of the current focus of common bean breeding programs in Brazil is to increase iron $(\mathrm{FeC})$ and zinc content $(\mathrm{ZnC})$ in grains. The objectives of this study were to estimate genetic parameters for $\mathrm{FeC}$ and $\mathrm{ZnC}$ in common bean, verify the need for conducting multi-site evaluation tests, identify elite lines that combine high $\mathrm{FeC}$ and $\mathrm{ZnC}$ with good adaptability, stability, and agronomic potential, and examine the genetic association between $\mathrm{FeC}$ and $\mathrm{ZnC}$. Elite lines (140) were evaluated for important agronomic traits in multiple environments. In one trial, $\mathrm{FeC}$ and $\mathrm{ZnC}$ were evaluated and genetic parameters were estimated. Based on the high heritability estimates and significant selection gains obtained, the conditions for a successful selection was favorable. Of the 140 evaluated lines, 17 had higher $\mathrm{FeC}$ and $\mathrm{ZnC}$, and were included in the validation test (2013, five environments), specifically for the evaluation of $\mathrm{FeC}$ and $\mathrm{ZnC}$. The line by environment interaction for $\mathrm{FeC}$ and $\mathrm{ZnC}$ was detected, but it was predominantly simple. The environmental effect strongly influenced $\mathrm{FeC}$ and $\mathrm{ZnC}$. The environment Brasília/rainy season was selected as
\end{abstract}


the best evaluation site for preliminary tests for $\mathrm{FeC}$ and $\mathrm{ZnC}$, because it resulted in similar conclusions as the mean of the five environments. The lines CNFP 15701 and CNFC 15865 had higher FeC and $\mathrm{ZnC}$ and were highly adaptable and stable, and are recommended for utilization in breeding programs. The lines CNFC 15833, CNFC 15703, and CNFP 15676 showed excellent combined agronomic and nutritional traits, and were selected for the development of biofortified cultivars. Additionally, the genetic association between $\mathrm{FeC}$ and $\mathrm{ZnC}$ was detected.

Key words: Common bean; Elite lines; Biofortification; Line by environment interaction

\section{INTRODUCTION}

Low levels of iron and zinc in the human body are among the most common nutritional deficiencies in the world (Eguílaz et al., 2010). Therefore, is an imminent need for quality, lowcost foods that meet nutritional demands, especially in developing countries (Ribeiro, 2011). Breeding can increase the bioavailability of mineral concentrations in the edible portions of plants (White and Broadley, 2005), thereby providing enhanced nutritional quality, without additional food costs. Common bean (Phaseolus vulgaris L.) is an excellent option for this breeding because it is the most widely consumed legume in the world, and part of the daily diet of the Brazilian people (Broughton et al., 2003).

The availability of common bean cultivars with nutritional qualities, along with important agronomic traits, would contribute to the sustainability of the common bean production chain. To obtain a cultivar with all these properties, the best strategy is to assess the nutritional composition of the elite lines of breeding programs, which already have favorable agronomic traits. However, one of the current focus of common bean breeding programs in Brazil is to increase the iron $(\mathrm{FeC})$ and zinc content $(\mathrm{ZnC})$; therefore, more genetic variability studies are required to estimate genetic and phenotypic parameters, the genetic associations between these traits, and the genotype by environment interactions.

Several studies have reported the presence of genetic variation, indicating the possibility of selecting lines with higher content (Araújo et al., 2003; Ribeiro et al., 2008; Silva et al., 2012a). Although some lines with high $\mathrm{FeC}$ and $\mathrm{ZnC}$ have been identified, there are few reports of breeding programs that obtained improved lines for these minerals (Blair et al., 2009; Silva et al., 2012b; Pereira et al., 2014).

It is necessary to determine the correlation between $\mathrm{FeC}$ and $\mathrm{ZnC}$ in the grain, since this association can facilitate or hamper the selection of lines with high concentrations of both these minerals. Some studies reported positive intermediate correlations between $\mathrm{FeC}$ and $\mathrm{ZnC}$ (Cichy et al., 2009; Blair et al., 2009, 2010), but these were phenotypic and not genetic correlations. Most studies indicated that the inheritance of $\mathrm{FeC}$ and $\mathrm{ZnC}$ is quantitative (Cichy et al., 2009; Blair et al., 2009, 2010), although another study identified monogenic inheritance for $\mathrm{ZnC}$ (Cichy et al., 2005).

A previous study noted that there was a relevant genotype by environment interaction for these two minerals (Cichy et al., 2009), while other studies detected importance only for $\mathrm{ZnC}$ (Ribeiro et al., 2008; Blair et al., 2011) or FeC (Araújo et al., 2003). In contrast, the 
interaction has also been reported to be absent, or of little significance, for the two traits or only FeC (Ribeiro et al., 2008; Blair et al., 2011). Additionally, most of the studies addressing the identification of potential parents for these traits were evaluated in only a few environments. Since these traits are possibly quantitative, it is expected that the effect of the environment is strong, and that the genotype by environment interaction is also important.

Based on the above, the objectives of this study were: to estimate genetic and phenotypic parameters for $\mathrm{FeC}$ and $\mathrm{ZnC}$ in common bean grains; to detect effects of genotype by environment interaction; to determine the relevance of performing tests in different environments for selection of nutritionally superior lines; to identify elite lines that combine high $\mathrm{FeC}$ and $\mathrm{ZnC}$ with good adaptability and stability, and agronomic potential; and to detect genetic associations between $\mathrm{FeC}$ and $\mathrm{ZnC}$ in common bean grains.

\section{MATERIAL AND METHODS}

\section{Preliminary tests}

Preliminary tests are a step in the common bean breeding program of the Embrapa Rice and Beans, and are performed to evaluate breeding lines previously selected for various traits. These tests are used for the selection of lines that will eventually constitute the trials used to select cultivars, and therefore are evaluated in various environments and with plot sizes adequate for agronomic evaluation. One hundred and forty elite lines with different grain types, and derived from different crosses, were evaluated, and were grouped by grain type: carioca (cream with brown stripes), 68 lines; black, 30 lines; mulatinho (cream-colored grain), 16 lines; early-cycle carioca, 14 lines; and purple, 12 lines. The tests were conducted in 2011 at five environments (dry season: Carira-SE, Lavras-MG, and Lambari-MG; rainy season: Ponta Grossa-PR; and winter: Santo Antônio de Goiás-GO), using a randomized complete block design (three replicates) and plots $4.0 \mathrm{~m}$ long with two rows. Phenotypic evaluations were conducted for grain yield, plant architecture, lodging tolerance, and reaction to anthracnose (caused by Colletotrichum lindemuthianum) and angular leaf spot (caused by Phaeoisariopsis griseola), as described by Melo (2009). The $\mathrm{FeC}$ and $\mathrm{ZnC}$ in the grain were evaluated only in the Santo Antônio de Goiás trial, using samples of 50 grains from each plot (two replicates).

\section{Validation test}

Based on the results of the preliminary tests, 17 high $\mathrm{FeC}$ and $\mathrm{ZnC}$ elite lines/cultivars were selected, and validation tests were conducted to confirm the $\mathrm{FeC}$ and $\mathrm{ZnC}$ of the lines, and the effects of the genotype by environment interaction. In addition to these lines, five control genotypes were used (Pereira et al., 2014), three of which had high FeC and ZnC (G 6492, BRS Supremo, and BRS Cometa) and two cultivars had intermediate levels (Pérola and BRS Agreste).

The experiment was designed as a randomized block design (two replicates), with 3 $\mathrm{m}$ long one-row plots. In 2013, validation tests were established in five environments: Ponta Grossa-PR (dry season); Santo Antônio de Goiás-GO (winter season); and Ponta Grossa-PR, Santo Antônio de Goiás-GO, and Brasília-DF (rainy season). In these tests, only $\mathrm{FeC}$ and $\mathrm{ZnC}$ content was evaluated. Agronomic evaluation was not carried out in validation test because in preliminary tests these evaluations were performed with appropriately sized plots. 


\section{Determining grain concentrations of iron and zinc}

$\mathrm{FeC}$ and $\mathrm{ZnC}$ was determined from one sample per plot. This sample was analyzed by acid digestion of organic matter using a nitric:perchloric (2:1) mixture and atomic absorption flame spectrophotometry, adapted from the methods by the Association of Official Analytical Chemists (1995). After harvest, the grains were rapidly washed with deionized water and then dried (to $6.0 \%$ moisture) in an oven at $60^{\circ} \mathrm{C}$ for $12 \mathrm{~h}$. The dry beans were ground in a zirconium oxide ball mill (Retsch, MM200), sieved ( $\leq 200 \mathrm{mesh}$ ), and stored in polytetrafluoroethylene containers to prevent contamination of the metallic elements. The samples were weighed the day after grinding, to determine moisture balance, and then pre-digested with the acid mixture $\left(50^{\circ} \mathrm{C} / 30 \mathrm{~min}\right)$, followed by the acid digestion process $\left(100^{\circ} \mathrm{C} / 30 \mathrm{~min} ; 170^{\circ} \mathrm{C} / 3 \mathrm{~h}\right.$; cooling at room temperature; new addition of $2.0 \mathrm{~mL}$ of acid mixture; and digestion at $170^{\circ} \mathrm{C} / 3 \mathrm{~h}$ ). The extract was adequately diluted and read on an atomic absorption spectrophotometer (Agilent/Varian SpectrAA $50 \mathrm{~B}$ model), pre-calibrated with the standard curve for iron and zinc. Mean data were expressed on dry basis, based on moisture concentration of the sample, and obtained by the gravimetric method at $105^{\circ} \mathrm{C}$ to constant weight (Instituto Adolfo Lutz, 1995). The glassware and equipment used in the analysis were treated with a special washing process, including a decontamination step with a $5.0 \%$ nitric or hydrochloric acid solution (v/v) to eliminate any sources of contamination.

\section{Genetic and statistical analysis}

In the preliminary tests, individual variance analyses (ANOVA) were performed for all traits in all environments, using the $\mathrm{F}$ test. In the analyses of variance for $\mathrm{FeC}$ and $\mathrm{ZnC}$, except for the mean effect, all effects of the model were considered random. The genotype effect was considered random because the lines had never undergone selection for these nutrients and represented a population of elite lines obtained from the Embrapa breeding program. For the analysis of agronomic traits, the effects of means and lines were considered fixed. The joint analysis was performed only for grain yield, and considered the environmental effect as fixed.

For the other traits, the evaluations were carried out in only one replication per environment. The assessment in a particular environment was considered as one replication in a single randomized block analysis. $\mathrm{For} F \mathrm{Fe}$ and $\mathrm{ZnC}$, genetic and phenotypic parameters were estimated, such as genetic variances, environmental variances, genetic variation coefficients, index $\mathrm{b}$, heritability and associated error, and expected gains with selection, with a selection intensity of $20 \%$ of the best lines (Ramalho et al., 1993).

In the validation test, individual and joint analyses of variance were performed for $\mathrm{FeC}$ and $\mathrm{ZnC}$. The environmental and line effects were considered fixed, because the lines had already been selected for these traits in the preliminary tests and, consequently, no longer represented the original variability of the population. Means were compared using the ScottKnott test at $10 \%$ of probability (Scott and Knott, 1974). The experimental precision was evaluated using selection accuracy (SA; Resende and Duarte, 2007).

In the joint analysis, the contribution of each source of variation to the total variation was estimated using the coefficient of determination (Ramalho et al., 1998). Additionally, stability and adaptability for $\mathrm{FeC}$ and $\mathrm{ZnC}$ of the lines were analyzed by the method proposed by Nunes et al. (2005). This method standardizes the mean of the lines in the different environments by using the expression: 


$$
z_{i j}=\frac{\left(\bar{y}_{i j}-\bar{y}_{. j}\right)}{s_{. j}}
$$

where, $z_{i j}$ is the value of the standardized variable corresponding to line $i$ in environment $j$, $\bar{y}_{i j}$ is the mean of line $i$ in environment $j, \bar{y}_{. j}$ is the mean of environment $j$, and $S_{. j}$ is the phenotypic standard deviation between the means of lines in environment $j$, given by:

$$
S_{. J}=\sqrt{\sum_{i=l}^{t}\left(\frac{\bar{y}_{i j}-\bar{y}_{. j}}{t-1}\right)^{2}}
$$

Then, a constant (two) was added to the obtained $z_{\mathrm{ij}}$ values to eliminate negative values. In this way, the mean of the $z_{i j}$ values for one line is a measure of adaptability of the line $\left(z_{i}\right)$, and the coefficient of variation for $z_{i j}$ is an estimator of stability for each line $\left(\mathrm{CV}_{\mathrm{i}}\right)$. For the interpretation of stability, the stability estimator was considered excellent for lines with $\mathrm{CV}_{\mathrm{i}}$ below 20, good for lines between 20 and 30, and poor for lines above 30 .

The importance of the simple part of the genotype by environment interaction was determined by estimating the Spearman correlations between the means of $\mathrm{FeC}$ and $\mathrm{ZnC}$ in the different environments. The association between $\mathrm{FeC}$ and $\mathrm{ZnC}$ was assessed by estimating the phenotypic and genetic correlations between $\mathrm{FeC}$ and $\mathrm{ZnC}$ based on the mean of 22 lines tested in each of the five environments, and also based on the general mean of the lines (Vencovsky and Barriga, 1992). SAS and GENES (Cruz, 2013) software were used for the statistical and genetic analyses.

\section{RESULTS AND DISCUSSION}

\section{Preliminary tests}

For the carioca, black, and mulatinho types, there was genetic variability between lines for $\mathrm{FeC}$ and $\mathrm{ZnC}$, showing the presence of at least one contrast statistically different from zero $(\mathrm{P} \leq 0.01)$. For the other grain type, there was not genetic variability. Regarding to the genetic parameters, the genetic variance in relation to the environmental variance was high for all grain types. The heritability estimates were different from zero $(52.6-83.8 \%$ for $\mathrm{FeC}$, and $41.7-95.7 \%$ for $\mathrm{ZnC}$; medium to high magnitude), indicating the possibility of successful selection for $\mathrm{FeC}$ and $\mathrm{ZnC}$ in grain (Table 1).

These heritability values were similar to those reported in other studies, which showed estimates from $29.0-84.0 \%$ for both traits, considering lines obtained from different parents in biparental crosses (Cichy et al., 2005; Jost et al., 2009; Rosa et al., 2010; Buratto, 2012). However, Silva et al. (2012a) reported higher heritability estimates $(97.9 \%$ for $\mathrm{FeC}$ and $97.4 \%$ for $\mathrm{ZnC}$ ) in lines from different genetic backgrounds. 
The genetic variation coefficients (5.58 - 9.00\% and $8.51-9.04 \%$ for $\mathrm{ZnC}$ and $\mathrm{FeC}$, respectively) indicated favorable conditions for selection of these two nutrients (Table 1). Index $\mathrm{b}$ ranged from 0.85 - 4.72 for $\mathrm{ZnC}$ and from 1.05 - 2.28 for $\mathrm{FeC}$, being considered adequate (Resende and Duarte, 2007). The expected selection gain ranged from 5.05\% (carioca, $\mathrm{Zn}$ ) to $12.52 \%$ (mulatinho, $\mathrm{Zn}$; Table 1) and these values are similar to those reported by Jost et al. (2009), Rosa et al. (2010), and Buratto (2012). Overall, as a result of the genetic variability and high heritability of these traits, there is good potential for selection of lines with higher $\mathrm{FeC}$ and $\mathrm{ZnC}$.

Table 1. Estimates for genetic variance $\left(\sigma_{\mathrm{g}}^{2}\right)$, phenotypic variance $\left(\sigma_{\mathrm{F}}^{2}\right)$, environmental variance $\left(\sigma_{\mathrm{e}}^{2}\right)$, narrowsense heritability $\left(\mathrm{h}^{2}\right)$, associated error $\left[\mathrm{S}\left(\mathrm{h}^{2}\right)\right]$, coefficient of genetic variation $\left(\mathrm{CV}_{\mathrm{g}}\right)$, index $\mathrm{b}$, and expected gain with selection (GS\%), for iron and zinc concentrations in common bean grains, tested in Santo Antônio de Goiás during the winter of 2011.

\begin{tabular}{|c|c|c|c|c|c|c|c|c|c|}
\hline & $\sigma^{2} \mathrm{~g}$ & $\sigma_{\overline{\mathrm{F}}}^{2}$ & $\sigma_{\mathrm{e}}^{2}$ & $\mathrm{~h}^{2}$ & $\mathrm{~S}\left(\mathrm{~h}^{2}\right)$ & $\mathrm{CV}_{\mathrm{g}}$ & $\mathrm{b}$ & GS (\%) & Mean \\
\hline \multicolumn{10}{|c|}{ Iron concentration } \\
\hline Carioca & 25.02 & 47.53 & 22.51 & 52.64 & 11.40 & 8.51 & 1.05 & 9.07 & 58.74 \\
\hline Black & 30.54 & 36.44 & 5.89 & 83.82 & 5.81 & 9.04 & 2.28 & 11.22 & 61.14 \\
\hline Mulatinho & 30.92 & 38.65 & 7.73 & 79.99 & 10.00 & 8.43 & 2.00 & 11.92 & 65.93 \\
\hline \multicolumn{10}{|c|}{ Zinc concentration } \\
\hline Carioca & 2.66 & 6.37 & 3.71 & 41.70 & 14.04 & 5.58 & 0.85 & 5.05 & 29.21 \\
\hline Black & 6.35 & 9.13 & 2.78 & 69.55 & 10.94 & 7.33 & 1.51 & 8.04 & 34.38 \\
\hline Mulatinho & 9.99 & 10.44 & 0.45 & 95.70 & 2.15 & 9.00 & 4.72 & 12.52 & 35.11 \\
\hline
\end{tabular}

\section{Validation tests}

The coefficients of variation (CV) values were low for $\mathrm{FeC}$ and $\mathrm{ZnC}(4.1-9.3 \%)$, showing good experimental precision, which could be confirmed by the estimates of selective accuracy (SA), considered as high or very high $(\mathrm{SA} \geq 0.70)$ in four environments for $\mathrm{FeC}$ and in five environments for $\mathrm{ZnC}$ (Resende and Duarte, 2007). These results are similar to those obtained by Pereira et al. (2014) for the same traits.

The means for $\mathrm{FeC}$ in the trials ranged from $58.1-82.0 \mathrm{mg} / \mathrm{kg}$, representing a variation of $41 \%$ and indicating great diversity among the environments. For $\mathrm{ZnC}$, the variation between environments was $29.2-37.3 \mathrm{mg} / \mathrm{kg}$ (i.e., a difference of approximately $28 \%$ ). This wide variation can be explained by the geographical differences among the evaluation locations, which represent great climatic diversity: Santo Antônio de Goiás $(823 \mathrm{~m}$ a.s.l., latitude $16^{\circ} 29^{\prime} \mathrm{W}$, longitude $\left.49^{\circ} 18^{\prime} \mathrm{S}\right)$; Brasília (1171 m a.s.l., latitude $15^{\circ} 46^{\prime} \mathrm{W}$, longitude $\left.47^{\circ} 55^{\prime} \mathrm{S}\right)$; and Ponta Grossa (969 m a.s.l., latitude $25^{\circ} 05^{\prime} \mathrm{W}$, longitude $50^{\circ} 09^{\prime} \mathrm{S}$ ).

In addition, differences, especially for $\mathrm{Fe}$ and $\mathrm{Zn}$, were observed in the chemical composition of the sampled soils from the experimental areas. The highest $\mathrm{FeC}$ value $(82.0$ $\mathrm{mg} / \mathrm{kg}$ ) was noted for the Ponta Grossa/rainy season environment (2013), which had the second highest soil iron concentration and the most acidic soil of the environments tested. In general, acidic soils favor Fe absorption (Moraghan et al., 2002). For $\mathrm{ZnC}$, the highest mean value for the grain $(37.3 \mathrm{mg} / \mathrm{kg}$ ) was noted for the Brasília/rainy season environment (2013), where the soil zinc concentration was highest. Cichy et al. (2005) reported that $\mathrm{ZnC}$ in common bean grains is changed by the soil zinc concentration. According to Corte et al. (2003), the nutritional quality of common bean grains is determined by the genotype, and influenced by the prevailing environmental conditions during the plant cycle and grain development. Thus, 
changes in the chemical composition of common bean grains can be expected in response to soil conditions (soil type, $\mathrm{pH}$, fertility, texture, and organic matter) and to climatic variations (temperature, precipitation, photoperiod, and radiation; Ribeiro, 2010).

The joint analysis detected the presence of variability between lines for $\mathrm{FeC}(\mathrm{P} \leq$ 0.01 ) and $\mathrm{ZnC}$ (Table 2), indicating that even after the selection of lines with higher $\mathrm{FeC}$ and $\mathrm{ZnC}$ in preliminary tests, variation was still observed among the 22 elite lines. Several studies reported the presence of genetic variability for $\mathrm{FeC}$ and $\mathrm{ZnC}$ (Araújo et al., 2003; Ribeiro et al., 2008; Silva et al., 2012a). However, most evaluated accessions from genebanks or lines derived from biparental crosses (Beebe et al., 2000; Gelin et al., 2007; Ribeiro et al., 2008; Silva et al., 2012a; Carvalho et al., 2012; Pereira et al., 2014). Variability between lines with high agronomic potential has been rarely reported in the literature.

Table 2. Summary of the joint analysis of variance for iron and zinc grain concentration $(\mathrm{mg} / \mathrm{kg})$, using 22 common bean lines evaluated in five environments ${ }^{1}$ in validation tests during 2013.

\begin{tabular}{l|c|c|c|c|c|c|c|c|c}
\hline \multirow{2}{*}{ SV $^{2}$} & d.f. & \multicolumn{4}{|c|}{ Iron concentration } & \multicolumn{4}{c}{ Zinc concentration } \\
\cline { 3 - 11 } & & $\mathrm{SS}^{4}$ & $\mathrm{MS}^{5}$ & $\mathrm{P}$ value & $\mathrm{R}^{26}$ & $\mathrm{SS}$ & \multicolumn{1}{c}{$\mathrm{MS}$} & $\mathrm{P}$ value & $\mathrm{R}^{2}$ \\
\hline Block/environment & 5 & 168.2 & 33.6 & - & 0.01 & 136.6 & 27.3 & - & 0.02 \\
\hline Lines (L) & 21 & $4,014.1$ & 191.1 & 0.001 & 0.15 & $1,428.7$ & 68.0 & 0.001 & 0.26 \\
\hline Environments (E) & 4 & $17,094.8$ & $4,273.5$ & 0.001 & 0.64 & $2,709.6$ & 677.4 & 0.002 & 0.49 \\
\hline L x E & 84 & $3,310.0$ & 39.4 & 0.001 & 0.12 & 679.1 & 8.1 & 0.059 & 0.12 \\
\hline Residue & 105 & $2,059.0$ & 19.6 & - & 0.08 & 615.4 & 5.9 & - & 0.11 \\
\hline Total & 219 & $26,645.5$ & - & - & & $5,569.5$ & - & - & \\
\hline Mean & & & 65.4 & & & & 33.56 & & \\
\hline $\mathrm{CV}^{7}(\%)$ & & & 6.8 & & & & 3.70 & & \\
\hline $\mathrm{SA}^{8}$ & & & 0.95 & & & & 0.96 & &
\end{tabular}

${ }^{1}$ Five environments: dry (Ponta Grossa-PR); winter (Santo Antônio de Goiás-GO); rainy (Ponta Grossa-PR, Santo Antônio de Goiás-GO, and Brasília-DF); ${ }^{2} \mathrm{SV}$ : source of variation; ${ }^{3}$ d.f.: degrees of freedom; ${ }^{4} \mathrm{SS}$ : sum of squares; ${ }^{5} \mathrm{MS}$ : mean square; ${ }^{6} \mathrm{R}^{2}$ : coefficient of determination, obtained by ratio of the sum of squares of the respective effect by the total sum of squares; ${ }^{7} \mathrm{CV}$ : coefficient of variation; ${ }^{8} \mathrm{SA}$ : selection accuracy.

There were also significant differences between environments, confirming the results from the individual analyses. The environmental effect accounted for $64 \%$ of the total variation for $\mathrm{FeC}$ and $49 \%$ for $\mathrm{ZnC}$ (Table 2), indicating that the cultivation environment should be considered in the selection of biofortified cultivars to enable the expression of the full genetic potential of the lines.

Silva et al. (2012b) and Nchimbi-Msolla and Tryphone (2010) also detected a strong environmental effect on the expression of these traits. According to the authors, the line by season interaction has an influence, although low, on the grouping of lines with high and low nutrient levels. In Rio Grande do Sul, Brazil, Ribeiro et al. (2008) found no significant effect of the interaction of cultivar by location for $\mathrm{FeC}$, but observed significance for $\mathrm{ZnC}$. In this study, the line by environment interaction was significant for $\mathrm{FeC}$ and $\mathrm{ZnC}(\mathrm{P} \leq 0.06)$. In other words, the lines had different responses to environmental variations (Table 2), in agreement with results for FeC in Paraná (Araújo et al., 2003) and for FeC and ZnC in Goiás, Brazil (Pereira et al., 2014). Most research that has focused on the genetic control of $\mathrm{FeC}$ and $\mathrm{ZnC}$ in grains has reported that the inheritance is quantitative (Cichy et al., 2009; Blair et al., 2009, 2010). A pronounced genotype by environment interaction is therefore also expected, which is considered important for most studies with these traits (Araújo et al., 2003; Cichy et al., 2009; Pereira et al., 2014).

Genetic and environmental factors, and the genotype by environment interaction, affected $\mathrm{FeC}$ and $\mathrm{ZnC}$ in common bean grains. Thus, the identification of elite lines with 
adaptability and stability for these traits is extremely important, particularly since common bean is grown in most Brazilian states in three growing seasons per year, and using different levels of technology.

Six and five elite lines had particularly high $\mathrm{FeC}$ and $\mathrm{ZnC}$, respectively, with higher means than the controls for high $\mathrm{FeC}$ and $\mathrm{ZnC}$ (BRS Supremo, G 6492, and BRS Cometa; Table 3). The four superior lines for FeC (CNFP 15701, CNFRx 15602, CNFC 15865, and CNFM 15632) are worth mentioning, not only because they had the highest means, but also because they had the highest adaptability indices $\left(Z_{\mathrm{ij}}\right)$ and represented four different types (black, roxinho, carioca, and mulatinho). These four lines were also superior in the preliminary tests and repeated their good performance in the validation testing. The mean of the first four lines was $7 \%$ higher than the overall mean and $11 \%$ above the mean of the cultivar Pérola, which is the most widely cultivated cultivar in Brazil (Table 3).

The most stable lines were CNFM 15632 and CNFC 15703, with $\mathrm{CV}_{\mathrm{i}}$ lower than 20. For line CNFRx 15602, despite the high FeC and good adaptability, it was not very stable as it had inconstant performance in the different environments. The lines CNFP 15701, CNFC 15865, and CNFM 15632 had high mean, high adaptability, and good phenotypic stability (Table 3).

For ZnC, the four superior lines (CNFRx 15602, CNFP 15701, CNFRx 15865, and CNFC 15598) had high means and the highest adaptability indices $\left(Z_{i j}\right)$. These first four lines also stood out in the preliminary tests. The mean of the first four lines was $10 \%$ higher than the overall mean and $20 \%$ higher than the control, Pérola (Table 3). The most stable lines, having an ideal $\mathrm{CV}_{\mathrm{i}}\left(\mathrm{CV}_{\mathrm{i}}<20\right)$, were CNFP 15701, CNFC 15833, CNFC 15865, and CNFRx 15602. Therefore, the four lines cited initially (CNFRx 15602, CNFP 15701, CNFRx 15865, and CNFC 15598) associated high mean $\mathrm{ZnC}$ with high adaptability and good stability.

Table 3. Iron and zinc grain concentrations (means; $\mathrm{mg} / \mathrm{kg}$ ) and adaptability and stability parameters of 22 common bean lines evaluated in five environments in validation tests during 2013.

\begin{tabular}{|c|c|c|c|c|c|c|c|}
\hline \multirow[t]{2}{*}{ Line } & \multirow{2}{*}{$\mathrm{GT}^{1}$} & \multicolumn{3}{|c|}{ Iron concentration } & \multicolumn{3}{|c|}{ Zinc concentration } \\
\hline & & Means $^{2}$ & $\mathrm{Z}_{\mathrm{i}}^{3}$ & $\mathrm{CV}_{\mathrm{i}}{ }^{4}$ & Means & $\mathrm{Z}_{\mathrm{i}}$ & $\mathrm{CV}_{\mathrm{i}}$ \\
\hline CNFP 15701 & Black & $71.7^{\mathrm{a}}$ & 3.18 & 21.8 & $37.3^{\mathrm{a}}$ & 3.27 & 11.7 \\
\hline CNFRx 15602 & Purple & $71.1^{\mathrm{a}}$ & 2.75 & 41.1 & $37.1^{\mathrm{a}}$ & 3.29 & 17.8 \\
\hline CNFC 15865 & Carioca & $70.9^{\mathrm{a}}$ & 3.16 & 25.4 & $37.2^{\mathrm{a}}$ & 3.13 & 16.5 \\
\hline CNFM 15632 & Mulatinho & $69.0^{\mathrm{a}}$ & 2.76 & 16.4 & $34.9^{\mathrm{b}}$ & 2.45 & 32.6 \\
\hline CNFP 15685 & Black & $68.8^{\mathrm{a}}$ & 2.55 & 35.3 & $36.1^{\mathrm{a}}$ & 2.64 & 38.3 \\
\hline CNFP 15676 & Black & $68.8^{\mathrm{a}}$ & 2.46 & 20.7 & $33.4^{\mathrm{b}}$ & 1.98 & 26.6 \\
\hline CNFC 15833 & Carioca & $68.1^{\mathrm{b}}$ & 2.56 & 39.5 & $34.5^{\mathrm{b}}$ & 2.32 & 14.9 \\
\hline BRS Esplendor & Black & $67.8^{\mathrm{b}}$ & 2.42 & 33.9 & $34.2^{\mathrm{b}}$ & 2.29 & 26.6 \\
\hline CNFP 15678 & Black & $67.3^{\mathrm{b}}$ & 2.29 & 25.1 & $34.6^{\mathrm{b}}$ & 2.39 & 20.7 \\
\hline BRS Supremo $^{5}$ & Black & $67.0^{\mathrm{b}}$ & 2.30 & 22.4 & $34.0^{\mathrm{b}}$ & 2.16 & 26.7 \\
\hline CNFC15704 & Carioca & $66.1^{\mathrm{b}}$ & 2.11 & 33.3 & $30.1^{\mathrm{d}}$ & 0.82 & 40.1 \\
\hline G $6492^{5}$ & Black & $66.1^{\mathrm{b}}$ & 2.14 & 24.1 & $35.2^{\mathrm{b}}$ & 2.45 & 37.2 \\
\hline CNFC 15703 & Carioca & $65.8^{\mathrm{b}}$ & 2.04 & 16.7 & $32.6^{\mathrm{c}}$ & 1.73 & 35.6 \\
\hline CNFM 15647 & Mulatinho & $65.2^{\mathrm{b}}$ & 2.06 & 25.3 & $34.3^{\mathrm{b}}$ & 2.36 & 27.3 \\
\hline CNFRx 15598 & Purple & $64.8^{\mathrm{b}}$ & 1.89 & 22.5 & $36.4^{\mathrm{a}}$ & 2.88 & 25.7 \\
\hline BRS Agreste $^{5}$ & Mulatinho & $63.2^{\mathrm{c}}$ & 1.71 & 31.6 & $29.8^{\mathrm{d}}$ & 0.79 & 74.4 \\
\hline Pérola $^{5}$ & Carioca & $62.8^{\mathrm{c}}$ & 1.57 & 39.2 & $29.8^{\mathrm{d}}$ & 0.86 & 38.9 \\
\hline IAC Centauro & Mulatinho & $61.0^{\mathrm{c}}$ & 1.18 & 22.9 & $29.5^{\mathrm{d}}$ & 0.75 & 52.0 \\
\hline CNFC 15852 & \begin{tabular}{|l|} 
Carioca \\
\end{tabular} & $60.8^{\mathrm{c}}$ & 1.17 & 77.7 & $32.1^{\mathrm{c}}$ & 1.51 & 30.3 \\
\hline CNFC 15839 & Carioca & $59.1^{\mathrm{d}}$ & 0.72 & 105.3 & $31.9^{\mathrm{c}}$ & 1.43 & 24.7 \\
\hline BRS Cometa $^{5}$ & Carioca & $58.5^{\mathrm{d}}$ & 0.73 & 59.3 & $32.8^{\mathrm{c}}$ & 1.73 & 20.3 \\
\hline BRS MG Tesouro & Purple & $55.4^{\mathrm{d}}$ & 0.25 & 225.3 & $29.9^{\mathrm{d}}$ & 0.75 & 122.8 \\
\hline Means & & 65.4 & & & 33.6 & & \\
\hline
\end{tabular}

${ }^{1}$ Grain type; ${ }^{2}$ Means followed by the same letter do not differ significantly at the level of $10 \%$ (Scott-Knott procedure). ${ }^{3} \mathrm{Z}_{\mathrm{i}}$ : value of the standard variable (adaptability parameter); ${ }^{4} \mathrm{CV}_{\mathrm{i}}$ : coefficient of variation of the standard variable for each line (stability parameter). ${ }^{5}$ Control lines. 
The performance of these lines is shown in Figure 1, with above-mean performance in practically all environments, forming a circumscribed circle in the shape of a "full ball". This shows that they responded efficiently to environmental stimuli and with adequate performance predictability. In contrast, cultivar Pérola had less ability to accumulate $\mathrm{FeC}$ and $\mathrm{ZnC}$ in the grain than the other lines, forming a circumscribed circle in the shape of a "slack ball".

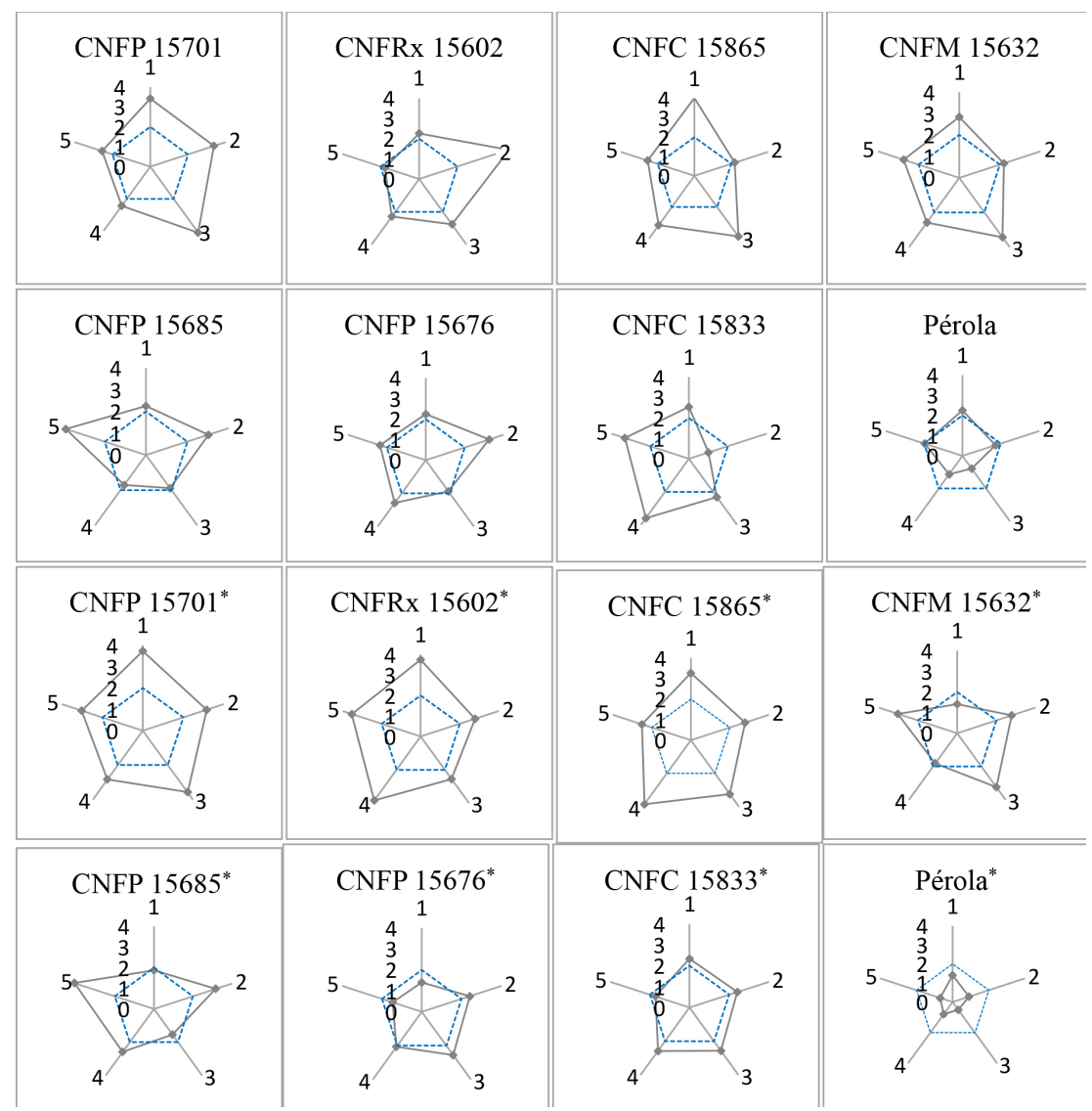

Figure 1. Performance graphs for $\mathrm{Fe}(\mathrm{FeC})$ and $\mathrm{Zn}$ content $(\mathrm{ZnC})$ of the superior elite lines and the cultivar Pérola (control) using the diagram method (Nunes et al., 2005). 1: Ponta Grossa-PR/dry season; 2: Santo Antônio de Goiás-GO/winter; 3: Brasília-DF/rainy season; 4: Ponta Grossa-PR/rainy; 5: Santo Antônio de Goiás-GO/rainy. $* \mathrm{ZnC}$.

Considering both nutritional traits, the lines CNFP 15701, CNFRx 15602, CNFC 15865, and CNFP 15685 were associated with the highest FeC and ZnC. Lines CNFP 15701 and CNFC 15865 were also highly adaptable and had good phenotypic stability (Table 3).

Elite lines facilitate the development of cultivars as they represent an outstanding group among the products of a breeding program, after undergoing several selection cycles, over several generations, for several traits. Among these, it is therefore possible to identify lines with an appropriate configuration, that is, lines that combine the different traits of interest. 
For the identification of elite lines with high $\mathrm{FeC}$ and $\mathrm{ZnC}$ and superior agronomic traits, the $\mathrm{FeC}$ and $\mathrm{ZnC}$ data of the validation tests were used, together with the agronomic data from the preliminary tests. Thus, the lines were compared with controls with the same grain type, and comparisons of agronomic traits were only performed for lines with proven high $\mathrm{FeC}$ and $\mathrm{ZnC}$.

Line CNFC 15865 had an excellent performance for $\mathrm{FeC}$ and $\mathrm{ZnC}$ in the validation tests, better than the cultivars Pérola and BRS Cometa, as well as in the preliminary test (Table 4). For grain yield, the performance of CNFC 15865 was similar to that of BRS Cometa and poorer to that of Pérola. In terms of tolerance to lodging, architecture, and reaction to anthracnose, line CNFC 15865 was superior to cultivar Pérola and similar to BRS Cometa. The lines CNFC 15833 and CNFC 15703 were also noteworthy for their intermediate nutritional performance, and with better performance for agronomic traits than all the cultivars (Table 4 and Figure 1).

Table 4. Means of elite lines and control cultivars for iron $(\mathrm{FeC})$ and zinc grain concentration $(\mathrm{ZnC})$, based on validation test, and grain yield (Prod; kg/ha), lodging (Lod), reaction to anthracnose (An), architecture (Arq), and reaction to angular leaf spot (Ls), (scores: 1 - 9), based on the preliminary tests.

\begin{tabular}{l|c|c|c|c|c|c|c|c|c|c}
\hline Lines & $\mathrm{GT}^{\mathrm{l}}$ & $\mathrm{FeC}$ & $\mathrm{ZnC}$ & $\mathrm{FeC}^{+}$ & $Z_{\mathrm{nC}}^{+}$ & Prod & Lod & An & Arq & Ls \\
\hline CNFC 15865 & $\mathrm{c}$ & $70.93^{\mathrm{a}}$ & $37.21^{\mathrm{a}}$ & 78.05 & 32.40 & $1.933^{\mathrm{d}}$ & $3.8^{\mathrm{a}}$ & $2.0^{\mathrm{a}}$ & $4.2^{\mathrm{a}}$ & $4.0^{\mathrm{a}}$ \\
\hline CNFC 15833 & $\mathrm{c}$ & $68.05^{\mathrm{b}}$ & $34.51^{\mathrm{b}}$ & 73.80 & 33.25 & $2.357^{\mathrm{b}}$ & $4.0^{\mathrm{b}}$ & $3.5^{\mathrm{a}}$ & $4.7^{\mathrm{b}}$ & $5.0^{\mathrm{a}}$ \\
\hline CNFC 15703 & $\mathrm{c}$ & $65.80^{\mathrm{b}}$ & $32.63^{\mathrm{c}}$ & 62.85 & 28.35 & $2.337^{\mathrm{a}}$ & $2.5^{\mathrm{a}}$ & $1.0^{\mathrm{a}}$ & $4.0^{\mathrm{a}}$ & - \\
\hline Pérola* & $\mathrm{c}$ & $62.80^{\mathrm{c}}$ & $29.77^{\mathrm{d}}$ & 66.25 & 29.70 & $2.656^{\mathrm{a}}$ & $4.5^{\mathrm{b}}$ & $6.0^{\mathrm{b}}$ & $5.0^{\mathrm{b}}$ & $4.3^{\mathrm{a}}$ \\
\hline BRS Cometa* & $\mathrm{c}$ & $58.49^{\mathrm{d}}$ & $32.83^{\mathrm{c}}$ & 62.05 & 30.90 & $1.911^{\mathrm{d}}$ & $3.8^{\mathrm{a}}$ & $2.5^{\mathrm{a}}$ & $3.2^{\mathrm{a}}$ & $4.0^{\mathrm{a}}$ \\
\hline CNFP 15701 & $\mathrm{p}$ & $71.71^{\mathrm{a}}$ & $37.35^{\mathrm{a}}$ & 71.51 & 40.81 & $2.117^{\mathrm{c}}$ & $4.4^{\mathrm{b}}$ & $3.5^{\mathrm{a}}$ & $3.6^{\mathrm{b}}$ & $6.0^{\mathrm{b}}$ \\
\hline CNFP 15676 & $\mathrm{p}$ & $68.84^{\mathrm{a}}$ & $33.41^{\mathrm{b}}$ & 65.15 & 37.84 & $2.557^{\mathrm{a}}$ & $2.8^{\mathrm{a}}$ & $1.0^{\mathrm{a}}$ & $3.2^{\mathrm{a}}$ & $1.0^{\mathrm{a}}$ \\
\hline BRS Esplendor & $\mathrm{p}$ & $67.80^{\mathrm{b}}$ & $34.20^{\mathrm{b}}$ & 82.64 & 37.74 & $1.685^{\mathrm{c}}$ & $4.4^{\mathrm{b}}$ & $1.0^{\mathrm{a}}$ & $3.6^{\mathrm{b}}$ & $5.5^{\mathrm{b}}$ \\
\hline BRS Supremo* & $\mathrm{p}$ & $67.03^{\mathrm{b}}$ & $33.97^{\mathrm{b}}$ & - & - & - & - & - & - & - \\
\hline G 6492* & $\mathrm{p}$ & $66.07^{\mathrm{b}}$ & $35.20^{\mathrm{b}}$ & - & - & - & - & - & - & - \\
\hline CNFM 15632 & $\mathrm{m}$ & $69.01^{\mathrm{a}}$ & $34.89^{\mathrm{b}}$ & 73.37 & 39.57 & $2.857^{\mathrm{b}}$ & $4.7^{\mathrm{a}}$ & $2.0^{\mathrm{a}}$ & $4.7^{\mathrm{a}}$ & - \\
\hline BRS Agreste* & $\mathrm{m}$ & $63.19^{\mathrm{c}}$ & $29.76^{\mathrm{d}}$ & 70.08 & 30.49 & $2.753^{\mathrm{b}}$ & $3.0^{\mathrm{a}}$ & $2.0^{\mathrm{a}}$ & $3.7^{\mathrm{a}}$ & - \\
\hline CNFRx 15602 & $\mathrm{pp}$ & $71.06^{\mathrm{a}}$ & $37.66^{\mathrm{a}}$ & 62.05 & 33.40 & $2.662^{\mathrm{a}}$ & $3.0^{\mathrm{a}}$ & $3.5^{\mathrm{a}}$ & $4.0^{\mathrm{a}}$ & - \\
\hline BRS MG Tesouro & $\mathrm{pp}$ & $55.35^{\mathrm{d}}$ & $29.89^{\mathrm{d}}$ & 64.85 & 29.25 & $2.146^{\mathrm{a}}$ & $3.0^{\mathrm{a}}$ & $3.0^{\mathrm{a}}$ & $5.0^{\mathrm{a}}$ & - \\
\hline
\end{tabular}

${ }^{1}$ GT Grain type; c: carioca; p: black; m: mulatinho; and r: purple. ${ }^{*}$ Controls. The cultivars used in the tests are underlined. For each GT, means followed by the same letter in a column do not differ significantly at the level of $10 \%$ (Scott-Knott procedure). ${ }^{+} \mathrm{FeC}$ and $\mathrm{ZnC}$ in the preliminary tests.

For $\mathrm{FeC}$ and $\mathrm{ZnC}$ in both validation and preliminary tests, the black seeded line, CNFP 15701, performed better than the other lines (Table 4). The performance for grain yield was superior or similar for lodging tolerance, architecture, and reaction to angular leaf spot for the CNFP 15701 line compared to the BRS Esplendor line. Line CNFP 15676 on the other hand showed intermediate performance for $\mathrm{FeC}$ and $\mathrm{ZnC}$ (Figure 1), but performed better for all agronomic traits compared to the controls and other tested lines.

Line CNFRx 15602 (roxinho type) had excellent performance for $\mathrm{FeC}$ and $\mathrm{ZnC}$ in the validation tests (Table 3 ). In the preliminary test, no significant differences were detected for any agronomic trait, between CNFRx 15602 and BRSMG Tesouro (control for the roxinho type), suggesting a high agronomic potential of CNFRx 15602 (Table 4).

In the mulatinho grain group, the best line was CNFM 15632, which had excellent values for $\mathrm{FeC}$ and good values for $\mathrm{ZnC}$ in the validation tests (Table 3). In the preliminary test, this line performed very well, better than the control cultivar BRS Agreste, confirming the good nutritional performance. In terms of agronomic traits, only grain yield differed significantly, and the grain yield of line CNFM 15632 was similar to that of BRS Agreste.

For the development of any biofortified cultivar, it is recommended to combine 
agronomic and nutritional traits, as well as adaptability and phenotypic stability. The lines CNFC 15833, CNFC 15703, and CNFP 15676 were selected for their potential as biofortified cultivars, based on their high agronomic potential, superiority in iron and zinc accumulation, great adaptability, and good stability (Tables 3 and 4; Figure 1).

\section{Identification of the environment for preliminary assessment of nutritional traits}

Once the genotype by environment interaction is detected for $\mathrm{FeC}$ and $\mathrm{ZnC}$ in the grains, the predominant type of interaction (simple or complex) must be identified, since this directly influences the selection process. From a practical point of view, it must be known whether only one environment is enough to identify promising lines or if multi-site tests are needed, which are cost-intensive.

For $\mathrm{FeC}$, the Spearman correlation estimates between environments were significant, positive, and moderate to strong, ranging from $0.40(\mathrm{P} \leq 0.05)$ to $0.72(\mathrm{P} \leq 0.01)$ (Table 5). The mean correlation between the different pairs of environments was 0.51 , indicating that the interaction is predominantly simple and that the classification of lines for $\mathrm{FeC}$ will not be significantly changed.

Table 5. Estimates of the Spearman correlation between the tested pairs for common bean and in the joint analysis, for $\mathrm{Fe}$ (below the diagonal line) and $\mathrm{Zn}$ grain concentration (above the diagonal), in $\mathrm{mg} / \mathrm{kg}$.

\begin{tabular}{|c|c|c|c|c|c|c|}
\hline Environment & PG/dry ${ }^{1}$ & SAG/win ${ }^{2}$ & BRA/rainy $^{3}$ & PG/rainy ${ }^{4}$ & SAG/rainy $^{5}$ & Mean $^{6}$ \\
\hline PG/dry & - & $0.68 * *$ & $0.70^{* *}$ & $0.70^{* *}$ & $0.76^{* *}$ & $0.85^{* *}$ \\
\hline SAG/win. & $0.42 * *$ & - & $0.62 * *$ & $0.59 * *$ & $0.77 * *$ & $0.76^{* *}$ \\
\hline BRA/rainy & $0.72 * *$ & $0.57 * *$ & - & $0.73 * *$ & $0.63 * *$ & $0.83^{* *}$ \\
\hline PG/rainy & $0.50^{* *}$ & $0.40^{*}$ & $0.48 * *$ & - & $0.70 * *$ & $0.88^{* *}$ \\
\hline SAG/rainy & $0.46^{* *}$ & $0.51 * *$ & $0.48 * *$ & $0.53 * *$ & - & 0.90 ** \\
\hline Mean $^{7}$ & $0.72 * *$ & $0.83 * *$ & $0.80 * *$ & $0.67 * *$ & $0.69 * *$ & - \\
\hline
\end{tabular}

${ }^{1} \mathrm{PG} /$ dry $=$ Ponta Grossa, dry season; ${ }^{2}$ Santo Antônio de Goiás, winter season; ${ }^{3} \mathrm{BRA}$ /rainy $=$ Brasília, DF, rainy season; ${ }^{4} \mathrm{PG} /$ rainy $=$ Ponta Grossa, rainy season; ${ }^{5} \mathrm{SAG} /$ rainy $=$ Santo Antônio de Goiás, rainy season; ${ }^{6}$ correlation between means of the joint analysis and means of the specific environment, for $\mathrm{ZnC}$; ${ }^{7}$ correlation between means of the joint analysis and means of the specific environment, for FeC. ${ }^{*}$ and ${ }^{* *}$ : significant at $5 \%$ and $1 \%(t$-test), respectively.

As a precaution, it is therefore recommended for $\mathrm{FeC}$ that in the final tests, where the number of lines is restricted and the selection pressure is strong, the evaluations be carried out in several environments. On the other hand, in preliminary tests, with lower selection pressure and a high number of lines, any of the five environments can be used as evaluation sites, since all were correlated with each other. The environment Brasília-DF/rainy stood out, since, of the five elite lines selected based on the combined mean, three coincided with the selection in this environment, indicating that this environment would have selected the same lines as the mean of the five environments.

For $\mathrm{ZnC}$, the Spearman correlations were also significant, positive, and moderate to strong, ranging from $0.59(\mathrm{P} \leq 0.05)$ to $0.77(\mathrm{P} \leq 0.01)$, with slightly higher magnitude than $\mathrm{FeC}$ (Table 5). The mean correlation between the different pairs of environments was 0.69 , indicating the predominance of simple interaction. For $\mathrm{ZnC}$, the simple interaction type was even more predominant, indicating that the genotype classification should not be changed.

All environments were strongly correlated with the mean, and any can be used for selection for increased $\mathrm{ZnC}$ in the grain. Since the evaluation for $\mathrm{FeC}$ and $\mathrm{ZnC}$ in the grain 
is performed simultaneously, Brasília-DF/rainy is recommended as the main preliminary evaluation site for elite lines.

\section{Relationship between iron and zinc concentrations in the grains}

The phenotypic correlation between $\mathrm{FeC}$ and $\mathrm{ZnC}$, based on the overall means of the lines, was significant $(\mathrm{P} \leq 0.01)$, positive, and high $(0.74)$. This was confirmed by the estimates of the five tests, ranging from $0.43(\mathrm{P} \leq 0.05)$ to $0.83(\mathrm{P} \leq 0.01)$. The magnitude of the correlation in the different experiments varied from intermediate to high, also indicating environmental influence on the association of these traits (Table 6). Our results were similar to those of other studies (Gelin et al., 2007; Cichy et al., 2009; Blair et al., 2009, 2010, 2011), all with recombinant inbreed lines derived from crosses between one parent with high and one with low $\mathrm{FeC}$ and $\mathrm{ZnC}$. In other studies using lines with different genetic backgrounds, a relationship between the two minerals was either refuted (Ribeiro et al., 2008) or confirmed (Nchimbi-Msolla and Tryphone, 2010; Silva et al., 2012a; Pereira et al., 2014). In general, the estimates of the above studies averaged 0.52 (ranged from -0.08 to 0.75 ).

Table 6. Estimates of the phenotypic $\left(r_{\mathrm{f}}\right)$, genetic $\left(\mathrm{r}_{\mathrm{g}}\right)$, and environmental correlations $\left(\mathrm{r}_{\mathrm{a}}\right)$ between the iron and zinc grain concentrations, based on the means of 22 common bean elite lines evaluated in each one of the five environments in validation tests during 2013 and based in general means of the lines.

\begin{tabular}{l|c|c|c}
\hline Environment & $\mathrm{r}_{\mathrm{f}}$ & $\mathrm{r}_{\mathrm{g}}$ & $\mathrm{r}_{\mathrm{a}}$ \\
\hline Ponta Grossa-PR/dry season & $0.46^{*}$ & $0.46^{\mathrm{ns}}$ & $0.45^{+}$ \\
\hline Santo Antônio de Goiás-GO/winter & $0.60^{* *}$ & $0.75^{++}$ & $0.13^{\text {ns }}$ \\
\hline Brasília-DF/rainy season & $0.83^{* *}$ & $0.96^{++}$ & $0.66^{++}$ \\
\hline Ponta Grossa-PR/rainy & $0.43^{*}$ & $0.54^{+}$ & $-0.18^{\text {ns }}$ \\
\hline Santo Antônio de Goiás-GO/rainy & $0.46^{*}$ & $0.60^{\text {ns }}$ & $0.33^{\text {ns }}$ \\
\hline General means & $0.74^{* *}$ & $0.81^{++}$ & $0.22^{++}$ \\
\hline
\end{tabular}

*,**Significant at 5 and $1 \%(t$-test $)$, respectively; ${ }^{+}$and ${ }^{++}$significant at 5 and $1 \%$ by the resampling by bootstrapping (Cruz, 2013).

There are few studies on the estimates of genetic correlation between $\mathrm{FeC}$ and $\mathrm{ZnC}$ in bean grains. Only the genetic correlation involves the inheritable nature of associations, which is of key interest in breeding programs (Falconer, 1987). Estimates of genetic correlations were similar to the phenotypic correlations, being positive, and intermediate to high, but significant in only three environments (Table 6). The mean genetic correlation was 0.81 (P $\leq 0.01$ ), indicating high association, exceeding the values observed by Silva et al. (2012a) and Pereira et al. (2014), 0.54 and $0.62(\mathrm{P} \leq 0.01)$, respectively. In other words, some of the genes that control these traits are linked and/or pleiotropic. The association between the two traits indicates the possibility of common metabolic pathways in the accumulation of the two minerals in common bean grain. The accumulation of both minerals in grain is controlled by the same quantitative trait loci (Blair et al., 2010).

Based on the results obtained, there is genetic variability in the $\mathrm{FeC}$ and $\mathrm{ZnC}$ between common bean elite lines from carioca, mulatinho, and black types and the selection conditions of elite lines with higher $\mathrm{FeC}$ and $\mathrm{ZnC}$ in the grains are favorable, because high heritability and significant gains with selection were observed. Additionally, the line by environment interaction for $\mathrm{FeC}$ and $\mathrm{ZnC}$ in common bean is predominantly simple; however, the environmental effect 
strongly influences $\mathrm{FeC}$ and $\mathrm{ZnC}$ in bean grains. The location Brasília-DF, in the rainy season, was identified as the best location for assessments of preliminary tests.

Furthermore, the lines CNFP 15701 and CNFC 15865 were not only superior in accumulating $\mathrm{Fe}$ and $\mathrm{Zn}$ in the grains, but also had high adaptability and good phenotypic stability. Once the agronomic and nutritional traits were combined, the lines CNFC 15833, CNFC 15703, and CNFP 15676 were selected as candidate biofortified cultivars.

\section{Conflicts of interest}

The authors declare no conflict of interest.

\section{ACKNOWLEDGMENTS}

The authors wish to thank the Federal University of Goiás for study opportunities and the Brazilian Coordination for the Improvement of Higher Education Personnel (CAPES) for the postgraduate scholarship of S.M.M. Embrapa Rice and Beans, the Brazilian Council for Scientific and Technological Development (CNPq), and the Harvest Plus program provided financial support for this research. P.G.S.M, H.S.P. and L.C.M, were supported by CNPq, with awards for technological development and innovative extension.

\section{REFERENCES}

Araújo R, Miglioranza E, Montalvan R, Destro D, et al. (2003). Genotype x environment interaction effects on the iron content of common bean grains. Crop Breed. Appl. Biotechnol. 3: 269-274. http://dx.doi.org/10.12702/1984-7033. v03n04a04

Association of Official Analytical Chemists (1995). The Official Methods of Analysis. AOAC International, Gaithersburg.

Beebe S, Gonzalez AV and Rengifo J (2000). Research on trace minerals in the common bean. Food Nutr. Bull. 21: 387 391. http://dx.doi.org/10.1177/156482650002100408

Blair MW, Astudillo C, Grusak M, Graham R, et al. (2009). Inheritance of seed iron and zinc content in common bean (Phaseolus vulgaris L.). Mol. Breed. 23: 197-207. http://dx.doi.org/10.1007/s11032-008-9225-z

Blair MW, Medina JI, Astudillo C, Rengifo J, et al. (2010). QTL for seed iron and zinc concentration and content in a Mesoamerican common bean (Phaseolus vulgaris L.) population. Theor. Appl. Genet. 121: 1059-1070. http://dx.doi. org/10.1007/s00122-010-1371-0

Blair MW, Astudillo C, Rengifo J, Beebe SE, et al. (2011). QTL analyses for seed iron and zinc concentrations in an intragenepool population of Andean common beans (Phaseolus vulgaris L.). Theor. Appl. Genet. 122: 511-521. http:// dx.doi.org/10.1007/s00122-010-1465-8

Broughton WJ, Hernández G, Blair M, Beebe S, et al. (2003). Bean (Phaseolus spp.): Model food legumes. Plant Soil 252: 55-128. http://dx.doi.org/10.1023/A:1024146710611

Buratto JS (2012). Teores de minerais e proteínas em grãos de feijão e estimativas de parâmetros genéticos. Doctoral thesis, Universidade Federal de Lavras, Ufla, Lavras.

Carvalho LMJ, Corrêa MM, Pereira EJ, Nutti MR, et al. (2012). Iron and zinc retention in common beans (Phaseolus vulgaris L.) after home cooking. Food Nutr. Res. 56: 1094-1103. http://dx.doi.org/10.3402/fnr.v56i0.15618

Cichy KA, Caldas GV, Snapp SS and Blair MW (2009). QTL analysis of seed iron, zinc, and phosphorus levels in an Andean bean population. Crop Sci. 49: 1742-1750. http://dx.doi.org/10.2135/cropsci2008.10.0605

Cichy KA, Forster S, Grafton KF and Hosfield GL (2005). Inheritance of seed zinc accumulation in navy bean. Crop Sci. 45: 864-870. http://dx.doi.org/10.2135/cropsci2004.0104

Corte AD, Moda-Cirino V, Scholz MBS and Destro D (2003). Environment effect on grain quality in early common bean cultivars and lines. Crop Breed. Appl. Biotechnol. 3: 193-202. http://dx.doi.org/10.12702/1984-7033.v03n03a03

Cruz CD (2013). Programa Genes: software in genetics and statistics. http://www.ufv.br/dbg/genes/genes.htm. Accessed 08 Jul 2013 
Eguílaz MHR, Santos CP, Navas-Carretero S and Hernández JAM (2010). Anemia ferropénica: estrategias dietéticas para su prevención. Actividad Dietética. 14: 67-71. http://dx.doi.org/10.1016/S1138-0322(10)70013-4

Falconer DS (1987). Introdução à genética quantitativa. (Silva MA and Silva JC, eds.). Universidade Federal de Viçosa, Viçosa.

Gelin JR, Forster S, Grafton KF, McClean PE, et al. (2007). Analysis of seed zinc and other minerals in a recombinant inbred population of navy bean (Phaseolus vulgaris L.). Crop Sci. 47: 1361-1366. http://dx.doi.org/10.2135/ cropsci2006.08.0510

Instituto Adolfo Lutz (1995). Métodos Físico-Químicos para Análise de Alimentos (Série A. Normas e Manuais Técnicos). Ministério da Saúde, Brasília.

Jost E, Ribeiro ND, Cerutti T, Poersch NL, et al. (2009). Potencial de aumento do teor de ferro em grãos de feijão por melhoramento genético. Bragantia 68: 35-42. http://dx.doi.org/10.1590/S0006-87052009000100005

Melo LC (2009). Procedimentos para Condução de Experimentos de Valor de Cultivo e Uso em Feijoeiro Comum. Embrapa Arroz e Feijão, Santo Antônio de Goiás.

Moraghan JT, Padilla J, Ethevers JD, Grafton K, et al. (2002). Iron accumulation in seed of common bean. Plant Soil 246: 175-183. http://dx.doi.org/10.1023/A:1020616026728

Nunes JAR, Ramalho MAP and Abreu AFB (2005). Graphical method in studies of adaptability and stability of cultivars. Annu. Rep. Bean Improv. Coop. 48: 182-183.

Nchimbi-Msolla S and Tryphone GM (2010). The effects the environment on iron and zinc concentrations and performance of common beans (Phaseolus vulgaris L.) genotypes. Asian J. Plant Sci. 9: 455-462. http://dx.doi.org/10.3923/ ajps.2010.455.462

Pereira HS, Del Peloso MJ, Bassinello PZ, Guimarães CM, et al. (2014). Genetic variability for iron and zinc content in common bean lines and interaction with water availability. Genet. Mol. Res. 13: 6773-6785. http://dx.doi. org/10.4238/2014.August.28.21

Ramalho MAP, Santos JB and Zimmerman MJO (1993). Genética quantitativa em plantas autógamas: aplicações ao melhoramento do feijoeiro. Universidade Federal de Goiás, Goiânia.

Ramalho MAP, Abreu AFB and Santos PSJ (1998). Interações genótipos x épocas de semeadura, anos e locais na avaliação de cultivares de feijão nas Regiões sul e Alto Paranaíba em Minas Gerais. Cienc. Agrotec. 22: 176-181.

Resende MDV and Duarte JB (2007). Precisão e controle de qualidade em experimentos de avaliação de cultivares. Pesq. Agropec. Trop. 37: 182-194.

Ribeiro ND (2011). Potencial de aumento da qualidade nutricional do feijão por melhoramento genético. Semina Cienc. Agrar. 31: 1367-1376. http://dx.doi.org/10.5433/1679-0359.2010v31n4Sup1p1367

Ribeiro ND, Jost E, Cerutti T, Maziero SM, et al. (2008). Micromineral composition of common bean cultivars and its application in crop breeding. Bragantia 67: 267-273.

Rosa SS, Ribeiro ND, Jost E, Reiniger LRS, et al. (2010). Potential for increasing the zinc content in common bean using genetic improvement. Euphytica 175: 207-213. http://dx.doi.org/10.1007/s10681-010-0163-6

Scott AJ and Knott M (1974). A cluster analysis method for grouping means in the analysis of variance. Biometrics 30: 507-512. http://dx.doi.org/10.2307/2529204

Silva CA, Abreu AFB, Ramalho MAP and Maia LGS (2012a). Chemical composition as related to seed color of common bean. Crop Breed. Appl. Biotechnol. 12: 132-137. http://dx.doi.org/10.1590/S1984-70332012000200006

Silva CA, Abreu AFB, Ramalho MAP and Corrêa AD (2012b). Interaction genotype by season and its influence on the identification of beans with high content of zinc and iron. Bragantia 71: 336-341. http://dx.doi.org/10.1590/S0006$\underline{87052012005000037}$

Vencovsky R and Barriga P (1992). Genética Biométrica no Fitomelhoramento. Sociedade Brasileira de Genética, Ribeirão Preto.

White PJ and Broadley MR (2005). Biofortifying crops with essential mineral elements. Trends Plant Sci. 10: 586-593. http://dx.doi.org/10.1016/j.tplants.2005.10.001 